\title{
Determining the Fisheries Consumption Preferences of Ege University Students
}

\author{
Hülya Sayg1 1,a," \\ ${ }^{1}$ Aquaculture Department, Faculty of Fisheries, Ege University, 35040 Bornova/İzmir, Turkey \\ *Corresponding author
}

\begin{tabular}{l|l}
\hline A R T I C L E I N F O & A B S T R A C T \\
\hline Research Article & $\begin{array}{l}\text { Demand for fishery products rich in protein, vitamin, mineral and omega fatty acids is increasing day } \\
\text { by day in order to meet the increasing nutritional needs of the world population. Despite being very } \\
\text { beneficial fisheries, the amount of consumption in Turkey is very low compared to other countries. } \\
\text { For this purpose, as an exemplary study, it has been tried to reveal the fishery consumption habits of } \\
\text { students studying at Ege University. Faculties in Ege University have been considered as layers. In } \\
\text { the study, a 25-question questionnaire was conducted face-to-face to 381 students selected according } \\
\text { to the random sampling method between February and March 2019, and the results were obtained. } \\
\text { The survey results obtained from the participants were evaluated using IBM SPSS 25.0 package } \\
\text { program. The obtained results were evaluated by Chi-square analysis and Principal Component } \\
\text { Analysis. Two group consumers emerged, representing coastal region 54.8\% and Terrestrial region } \\
\text { 45.2\%. It has been determined that the most important reason for fish consumption in preference } \\
\text { factors and availability is price. Ege University of students' Consumer profiles; It was found to be } \\
\text { different in terms of socio-demographic factors, consumption patterns, attitudes towards health and } \\
\text { healthy food. As a result, it was determined that the fishery products were not consumed at the desired } \\
\text { level in Ege University students. Accordingly, Ege University students should be made aware of } \\
\text { increasing their consumption of fisheries. For this purpose, it is recommended to carry out } \\
\text { promotions, advertisements and promotions that prove healthy. }\end{array}$ \\
$\begin{array}{l}\text { Keywords: } \\
\text { Student } \\
\text { Consumption }\end{array}$ \\
$\begin{array}{l}\text { Fisheries } \\
\text { Basic Components Analysis }\end{array}$
\end{tabular}

Türk Tarım - Gıda Bilim ve Teknoloji Dergisi, 8(12): 2785-2789, 2020

\section{Ege Üniversitesi Öğrencilerinin Su Ürünleri Tüketim Tercihlerinin Belirlenmesi}

\begin{tabular}{|c|c|}
\hline M A K A L E B İ L G İ S İ & Ö Z \\
\hline $\begin{array}{l}\text { Anahtar Kelimeler: } \\
\text { Ege Üniversitesi } \\
\text { Öğrenci } \\
\text { Tüketim } \\
\text { Su Ürünleri } \\
\text { Temel Bileşenler Analizi }\end{array}$ & $\begin{array}{l}\text { Dünya nüfusunun günümüzde artan beslenme ihtiyacını karşılamak amacıyla protein, vitamin, } \\
\text { mineral ve omega yağ asitleri yönünden zengin su ürünlerine talep gün geçtikçe artmaktadır. } \\
\text { Balıkçılık çok faydalı olmasına rağmen Türkiye'deki tüketim miktarı diğer ülkelere göre oldukça } \\
\text { düşüktür. Bu amaçla, Örnek bir çalışma olması açısından, Ege Üniversitesinde okuyan öğrencilerin } \\
\text { su ürünleri tüketim alışkanlıkları ortaya çıkarılmaya çalışılmıştır. Ege Üniversitesinde bulunan } \\
\text { fakülteler katman olarak ele alınmıştır. Çalışma, Şubat-Mart } 2019 \text { tarihleri arasında rasgele örnekleme } \\
\text { yöntemine göre seçilen } 381 \text { öğrenciye } 25 \text { soruluk bir anket yüz yüze yapılmış ve sonuçlar elde } \\
\text { edilmiştir. Katılımcılardan alınan anket sonuçları IBM SPSS } 25.0 \text { kullanılarak değerlendirilmiştir. } \\
\text { Elde edilen sonuçlar Ki-kare analizi ve Temel Bileşen Analizi ile değerlendirilmiştir. Anket } \\
\text { katılımcılarının \%54,8'i kıyısal bölgeden ve \%45,2'si karasal bölgeden gelen tüketiciler olarak tespit } \\
\text { edilmiştir. Tercih faktörlerinde ve bulunabilirlikte balık tüketimindeki en önemli nedenin fiyat olduğu } \\
\text { tespit edilmiştir. Tüketici profillerinin; sosyo-demografik faktörler, tüketim kalıpları, sağlık ve } \\
\text { sağlıklı gıdaya yönelik tutumlar açısından farklı olduğu bulunmuştur. Sonuç olarak Ege Üniversitesi } \\
\text { öğrencilerinde su ürünlerinim istenilen düzeyde tüketilmediği saptanmıştır. Buna göre Ege } \\
\text { Üniversitesi öğrencilerinin su ürünleri tüketimini artırma konusunda bilinçlendirilmesi } \\
\text { gerekmektedir. Bu amaçla, Sağlıklı olduğunu kanıtlayan promosyon, reklam ve promosyonların } \\
\text { yapılması tavsiye edilir. }\end{array}$ \\
\hline
\end{tabular}




\section{Introduction}

Food preferences of consumers, the food itself sensory properties of individual-specific factors (such as do not like certain foods) and environmental, includes a complex interaction between cultural and contextual influences (Furst, et al., 1996; Geslani et al., 2015; Almedia et al., 2015; Cardoso et al. 2016). Food choices increasingly reflect people's personalities and lifestyles more (Kim et al., 2005; Brunsø et al, 2009; Tolon and Elbek, 2016; Thong and Solgaard, 2017), to determine the motive of different food choices that emphasize the role of the owner. To understand the reasons determining the choice of food, it is important to design the promotional campaign successfully and is required for the development of effective food and health policy. Fish is an important source of protein and not much fish is a popular pastime in many places (Pieniak et al., 2010; Mitchel, 2011; Lyerly and Reeve, 2015).

The importance of nutrition and health in the optimal development of public health is well known. The American Heart Association and the organizations and institutions that determine optimal nutrition standards in Turkey, public health suggest at least 300-450 $\mathrm{g}$ of fish consumption per week to protect from chronic diseases such as cardiovascular disease (Pieniak et al., 2010; Mitchel, 2011; Cardoso et al., 2016). Those who consumed fish, consumed in food oils, rich in unsaturated fats that are very important for human health. Because $\omega-3$ series fatty Acids in fish play an importance role in biochemical and physiological activities in the human body. Fatty acids in the human body, eyes, brain, testes and placenta are collected. Your eyes are working properly and fully perform the functions of the brain helps. Regulates the concentration of fat in the blood (Foxal et al., 1998; Cardoso et al., 2016). As a result, these fatty acids, heart attack, cardiovascular disease, depression, migraine-type headaches, joint rheumatism, diabetes, high cholesterol and blood pressure, certain allergic types of cancer many diseases in the prevention of significant effects were found (Pieniak et al., 2010; Cardoso et al., 2016).

The health problems occur in those who do not consume fish. Fish is low in saturated fats and high in nutrients, readily available. While meat and fish are the two main sources of protein, the meat is more popular than fish, in spite of general consumer beliefs to the effect that red meat, in particular, may have unhealthy properties. People may be averse to consuming fish because of a Perceived difficulty in buying, preparing and cooking it, the belief that it is expensive or the unpleasant physical properties of some varieties of fish such as the bones and the smell (Leek, et al, 2000).

Fisheries products are an important source of animal protein for human consumption due to diet. Despite the increase in the population, fisheries products consumed in our country is not enough. information about the reasons why the potential to affect the consumer has the choice of food consumption decisions, food and health policy, as well as marketing strategies are important when designing.

In this study is aims to present an assessment of Ege University of students consumer attitudes in general. The aim of this study is to divide the Izmir demand according to consumer perceptions and define a set of clusters, preferably consisting of open socio-demographic and behavioural profiles.

\section{Material and Methods}

The measurements used in this study are mainly based on currently valid scales. In order to reveal the motive segments of Izmir that overlook the consumers, variables proven to be associated with food preference motives were used.

It is planned by this study that the public opinion about fish culture in Ege University of students was determined. Therefore, the faculties Ege University of students was accepted as a layer and data were collected by 381 people randomly with a poll selected through face to face interviews.

The questionnaire form includes a group of questions determining the knowledge and attitudes about food purchasing, consumption, and food poisoning and sociodemographic variables.

Reasons for food choice were measured by the application of the food choice questionnaire (Steptoe et al., 1995; Honkanen and Frewer, 2009). The questionnaire prepared for this study has been changed to the fish consumption questionnaire.

The fisheries products questionnaire consists of 17 items that make up 5 motivation factors in the current study: healthy, usability, difficulties, substitution. Participants were asked to rate the statement "the fish I eat on a typical day is important to me" for each item and evaluate its significance on a scale from $1=$ not important to $7=$ very important.

All data were analysed by the IBM SPSS Statistics for Windows, Version 25.0 statistical program. In order to determine the factors affecting fish consumption, KhiSquare $\left(\chi^{2}\right)$, a multidimensional parameter, principal component analysis (PCA) was used as well as percentage distribution (Zar, 2010).

\section{Results and Discussion}

It was determined that the rate of those who consumed fish once a week was $31 \%$. In addition, households prefer fish resources when purchasing fish due to their freshness, hygienic conditions and other needs.

When the answers of students coming from coastal and terrestrial regions are examined, statistical differences were determined only according to the income variable. Other variables did not differ significantly between coastal and onshore regions (Table 1). Therefore, all variables are considered as a whole.

Descriptive statistics for socio-demographic data of the participants are given in Table 2. The fit factor in the original questionnaire is also divided into the eligibility and usability dimensions as a result of the different scores provided by the individual respondents. Principal component analysis (PCA) was performed on motivated items. Although some items had low parameter estimates, the results were acceptable, all were significant. The general model can also be accepted considering the sample size $\left(\chi^{2}=6747.66\right.$; $\mathrm{df}=136 ; \mathrm{p}=$ 0.000; Kaiser-Meyer-Olkin Sampling Adequacy Measurement $=0.832$ ). The predictions are compared with the original Steptoe et al. (1995) paper and they are quite similar. FA results and reliability of factors (Cronbach alphas) are shown in Table 3. 
Table 1. Comparison of Coastal and Terrestrial Regions

\begin{tabular}{|c|c|c|c|c|}
\hline \multirow{2}{*}{ Variables } & \multicolumn{2}{|c|}{ Regional Segregation } & \multirow{2}{*}{$\chi^{2}$} & \multirow{2}{*}{$\mathrm{p}$} \\
\hline & Coastal $(54.8 \%)$ & Terrestrial $(45.2 \%)$ & & \\
\hline Gender & & & 0.047 & $0.939^{\text {ns }}$ \\
\hline Male & $46 \%$ & $48 \%$ & & \\
\hline Female & $54 \%$ & $52 \%$ & & \\
\hline Age & & & 4.455 & $0.982^{\mathrm{ns}}$ \\
\hline Under 18 & $8 \%$ & $3 \%$ & & \\
\hline $19-20$ & $34 \%$ & $44 \%$ & & \\
\hline $21-22$ & $25 \%$ & $23 \%$ & & \\
\hline $23-24$ & $20 \%$ & $22 \%$ & & \\
\hline 25 up & $13 \%$ & $9 \%$ & & \\
\hline Income (\$) & & & 31.217 & $0.000 *$ \\
\hline$<50$ & $11 \%$ & $32 \%$ & & \\
\hline $51-100$ & $34 \%$ & $19 \%$ & & \\
\hline $101-150$ & $30 \%$ & $37 \%$ & & \\
\hline $151-200$ & $18 \%$ & $11 \%$ & & \\
\hline$>201$ & $24 \%$ & $2 \%$ & & \\
\hline
\end{tabular}

Table 2. Socio-demographic profile, overall sample $(\mathrm{n}=381)$.

\begin{tabular}{|c|c|c|}
\hline Variables & Frequency & Percent $(\%)$ \\
\hline \multicolumn{3}{|l|}{$\operatorname{Sex}$} \\
\hline Male & 179 & 47 \\
\hline Female & 202 & 53 \\
\hline \multicolumn{3}{|l|}{ Age } \\
\hline Under 18 & 23 & 6 \\
\hline $9-20$ & 145 & 39 \\
\hline $21-22$ & 95 & 25 \\
\hline $23-24$ & 72 & 19 \\
\hline 25 up & 46 & 12 \\
\hline \multicolumn{3}{|l|}{ Income $(\$)^{*}$} \\
\hline$<50$ & 99 & 26 \\
\hline $51-100$ & 76 & 20 \\
\hline $101-150$ & 126 & 34 \\
\hline $151-200$ & 53 & 14 \\
\hline$>201$ & 27 & 7 \\
\hline \multicolumn{3}{|l|}{ Job } \\
\hline Part time & 149 & 39 \\
\hline Unemployed & 232 & 61 \\
\hline \multicolumn{3}{|l|}{ Fish consumption } \\
\hline More than twice a week & 15 & 4 \\
\hline Twice a week & 110 & 30 \\
\hline One a week & 114 & 31 \\
\hline Inside of two week & 107 & 29 \\
\hline Less than one month & 34 & 10 \\
\hline \multicolumn{3}{|l|}{ Region } \\
\hline Coastal & 210 & 55 \\
\hline Terrestrial & 171 & 45 \\
\hline
\end{tabular}

*12.04.2018 (1.00 TL= 4.82\$)

In order to reveal the factors affecting consumers' preferences, varimax rotation principal component factor analysis (Hackett and Foxal, 1999) was performed on the survey data and a four-factor solution with eigenvalues greater than 1 was produced. Examination of a scree plot of eigenvalues confirmed that these four factors taken together accounted for almost $81 \%$ of the cumulative variance.

Varimax rotational PCA identified four factors with an eigenvalue greater than 1 (Table 3), accounting for $\% 81.113$ of the total variance, and were approximately equally significant. According to the PCA results, the preferences of Ege University students can be evaluated with 4 factors out of 17 items and these factors are related to the attitudes of consumers. These factors include Health (Fish makes a good family meal, Fish is readily available in the shops, Fish is nutritious food, Fish is healthy food, I like to serve fish when I have guests), Usability (Fish provides good value for money, There are lots of different varieties of fish, Fish can be used in many different recipes, Fish is versatile), Difficulties (Fish has an unplesant smell, There is a danger of food poisoning, Fish is difficult to 
prepare, Fish is expensive, Fish provides an alternative to red meat Fish goes off quickly), substitution (A prefer chicken), These more uniform Likert agreement statements are likely to be necessary to clearly demonstrate the emergence of key selection factors.

In Turkey, seafood consumption preferences Factors affecting reveal aimed the desired conclusion, According the to the seafood marketing and consumption is still at the Desired level an effect or not, no seafood consumed a part of the well is located has emerged. Working conditions of the region are taken into consideration due to geographical features and economic conditions, and unknown types of seafood are consumed. To raise awareness of the consumers, the quality of aquatic products, feed consumption and economy information about the value must be explained to consumers. Local Authorities and other regional Institutions and Organizations in for their area of interest to the public should be Encouraged seafood products and promotional activities. Consumption in Turkey promoters and encourage the expansion of activities in the market, Recruiters must be required to the increased consumption (Bashimov, 2017; Selvi et al., 2019; Genç et al., 2020).

Table 3. Factor analysis (standardized parameters) and Reliabilities of the motive factors (Chronbach's alpha)

\begin{tabular}{|c|c|c|c|c|c|}
\hline Parameters & & $\begin{array}{c}\text { Cronbach's } \\
\text { alpha }\end{array}$ & Eigenvalue & $\begin{array}{c}\% \text { of Variance } \\
\text { explained }\end{array}$ & $\begin{array}{c}\text { \% Cumulative } \\
\text { Variance }\end{array}$ \\
\hline Factor I & & 0.824 & 7.599 & 44.699 & 44.699 \\
\hline Fish makes a good family meal & 0.951 & & & & \\
\hline Fish is readily available in the shops & 0.939 & & & & \\
\hline Fish is nutritious food & 0.648 & & & & \\
\hline Fish is healthy food & 0.796 & & & & \\
\hline I like to serve fish when I have guests & 0.590 & & & & \\
\hline Factor II & & 0.750 & 3.464 & 20.378 & 65.077 \\
\hline Fish provides good value for money & 0.872 & & & & \\
\hline There are lots of different varieties of fish & 0.858 & & & & \\
\hline Fish can be used in many different recipes & 0.794 & & & & \\
\hline Fish is versatile & 0.616 & & & & \\
\hline Factor III & & 0.715 & 1.685 & 9.909 & 74.986 \\
\hline Fish has an unpleasant smell & 0.865 & & & & \\
\hline There is a danger of food poisoning & 0.846 & & & & \\
\hline Fish is difficult to prepare & 0.813 & & & & \\
\hline Fish is expensive & 0.835 & & & & \\
\hline Fish goes off quickly & 0.712 & & & & \\
\hline Factor IV & & 0.710 & 1.042 & 6.127 & 81.113 \\
\hline A prefer chicken & 0.857 & & & & \\
\hline Fish provides an alternative to red meat & 0.642 & & & & \\
\hline
\end{tabular}

Economic theory Suggests that the main determinants of changes in food consumption are changes in real consumer income, in the product price, and in the prices of complementary and substitute goods as well as preferences and sociodemographic faktörü (Almedia et al., 2015; Cardoso, 2016; Rahnama and Somogyi, 2020).

As a result of this study, the majority of participants frequently claimed that they consume fish more than once a week. Ege University students' income as certain sociodemographic parameters of fish consumption in particular has emerged as an effective predictor. Today's society and of future generations to increase their fish consumption habits and create healthy is a basic fact. In this case, periodic updating should be supported by aquaculture and consumption of these products should be supported in terms of short and long term benefits (cancer effects, cardiovascular health, diabetes delay, depression, aging, memory loss, inflammation and migraine). for human health. pain prevention) should be explained. Within the education system and value, the importance of seafood in a family environment for children should be told, starting from primary school level students definitions of fishery products should be transferred to the theoretical and practical. In addition, we have resources and sustainable production processes with the implementation of 850 thousand tons of fish produced approximately per year, and in this regard would be possible obtaining healthy food should not be forgotten to may rise from the centre of the problem.

\section{References}

Almeida C, Altintzoglou T, Cabral H, Vaz S. 2015. Does seafood knowledge relate to more sustainable consumption?. British Food Journal, 117(2): 894-914. https://doi.org/10.1108/bfj04-2014-0156

Bashimov G. 2017. Determining fish meat consumption habits in Nigde Province. Turkish Journal of Agricultural and Natural Sciences, 4(2): 196-204.

Brunsø K, Verbeke W, Olsen SO, Jeppesen LF. 2009. Motives barriers and quality evaluation in fish consumption situations: Exploring and comparing heavy and light users in Spain and Belgium. British Food Journal, 111:699-716. https://doi.org/10.1108/00070700910972387

Cardoso C, Lourenço H, Costa S, Gonçalves S, Leonor Nunes M. 2016. Survey into the seafood consumption preferences and patterns in the Portuguese population: education, age, and health variability. Journal of Food Products Marketing, 22(4):421-435.

https://doi.org/10.1080/10454446.2014.949982

Foxall G, Leek S, Maddock S. 1998. Cognitive antecedents of consumers' willingness to purchase fish rich in polyunsaturated fatty acids (PUFA). Appetite 31:391-402. https://doi.org/10.1006/appe.1998.0178 
Furst T, Connor M, Bisogni CA, Sobal FJ, Falk LW. 1996. Food choice: a conceptual model of the process. Appetite, (26) 247-266. https://doi.org/10.1006/appe.1996.0019

Genç Y, Albayrak M, Güldal HT. 2020. Balık tüketiminde tüketim tercihlerini etkileyen faktörlerin analizi: Çankırı İli örneği. Analysis of factors affecting consumption preferences in fish consumption: Case of Çankırı Province. Ege Journal of Fisheries and Aquatic Sciences 37(1):93-101. https://doi.org/10.12714/egejfas.37.1.11

Geslani C, Loke MK, Barnes-Mauthe M, Leung P. 2015. Seafood purchasing preferences of Hawaii chefs: comparing actual purchase to stated preferences from conjoint choice experiment. Journal of International Food and Agribusiness Marketing, 27(1):50-63. https://doi.org/10.1080/08974438. 2013.833569

Hackett, P. M., \& Foxall, G. R. (1994). A factor analytic study of consumers' location specific values: a traditional high street and a modern shopping mall. Journal of Marketing Management, 10(1-3), 163-178.

Honkanen P, Frewer L. 2009. Russian consumers' motives for food choice. Appetite, 52: 363-371. https://doi.org/ 10.1016/j.appet.2008.11.009

Kim BE, Cho YJ, Shim KB. 2005. A Study on Preference and Promoting' Consumption of Slice Raw Fish to Conduct a Questionnaire Survey of Citizens of Busan. Journal of Fisheries and Marine Sciences Education 17(3):413-426.

Leek S, Maddock S, Foxall G. 2000. Situational determinants of fish consumption. British Food Journal, 102:18-39. https://doi.org/10.1108/00070700010310614

Lyerly JE, Reeve CL. 2015. Development and validation of a measure of food choice values. Appetite, 89:47-55. https://doi.org/10.1016/j.appet.2015.01.019
Mitchell M. 2011. Increasing fish consumption for better health are we being advised to eat more of an inherently unsustainable protein?. Nutrition Bulletin, 36(4):438-442. https://doi.org/10.1111/j.1467-3010.2011.01926.x

Pieniak Z, Verbeke W, Scholderer J. 2010. Health- related beliefs and consumer knowledge as determinants of fish consumption. Journal of Human Nutrition and Dietetic, 23(5), 480-488. https://doi.org/10.1111/j.1365-277x.2010.01045.x

Rahnama H, Somogyi S. 2020. Northern Iranian Consumers' Motivation for Seafood Choice. Journal of International Food and Agribusiness Marketing, 33:1-23. https://www.tandfonline.com/ doi/full/10.1080/08974438.2020.1737617 https://doi.org/10.1080/08974438.2020.1737617

Selvi K, Kandemir G, Özdikmenli Tepeli S. 2019. Determination of factors affecting on the fish consumption habit in rural areas: The case of Çan (Çanakkale). COMU Journal of Marine Science and Fisheries, 2(2): 132-141.

Steptoe, A., Malik, F., Pay, C., Pearson, P., Price, C., \& Win, Z. (1995). The impact of stage fright on student actors. British Journal of Psychology, 86(1), 27-39.

Thong NT, Solgaard HS. 2017. Consumer's food motives and seafood consumption. Food Quality and Preference, 56:181188. https://doi.org/10.1016/j.foodqual.2016.10.008

Tolon MT, Elbek AG. 2016. Determination of factors affecting seafood consumption pattern and consumption frequency. Ege Journal of Fisheries and Aquatic Sciences, 33(3), 271277. https://doi.org/10.12714/egejfas.2016.33.3.12

Zar J H. 2010. Biostatistical Analysis., 5th edn. (Prentice Hall Inc.: New Jersey). 